\title{
Core Ethical Values of Character Education Based on Sundanese Culture Value
}

\author{
Hisny Fajrussalam ${ }^{1}$, Aan Hasanah ${ }^{2}$ \\ ${ }^{1,2}$ Postgraduate Program, State Islamic University (UIN) Sunan Gunung Djati Bandung, Indonesia \\ 1hfajrussalam@gmail.com, ${ }^{2}$ aanhasanah11@yahoo.com
}

\section{Keywords:}

Character education, Ethical values, Sundanese culture

\section{ABSTRACT}

This paper is motivated by the moral decadence that occurs in West Java as a Sundanese society. This paper intends to re-explore ethical values that should be the basis of Sundanese people's lives in West Java. This research uses qualitative. Data taken from the author's observational that are felt and experienced in everyday life. Research shows that education takes an important role in efforts to foster a moral attitude of society. Education in question is character education based on Sundanese cultural values. So hopefully the community can become an identity that always holds the wisdom of a good Sundanese culture. Some ethical values of Sundanese culture that can be found are welfare, health, care for the environment, moderate, hard work, discipline, politeness, honesty, upholding the truth, mutual cooperation, social solidarity, positive thinking, mature calculation, education, gender management, preservation and preservation Sundanese culture. The values of Sundanese culture can be classified into 2 (two), namely prosperity/welfare and peace/goodness that are all reflected in outlook on life, oral traditions, language, and pro-social behavior. These values are very relevant to the essential value of the Koran. Based on the values inherent in the Sundanese community, it should be able to create a climate that brings the community to Islamic values. Thus, we will go to the society that Islam aspires for, namely a society where every aspect of life breathes religious values.

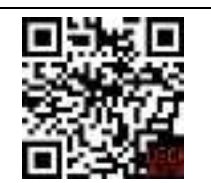

\section{Article History:}

Received: $12-10-2018$

Revised : 26-12-2018

Accepted: 28-12-2018

Online : $30-12-2018$

This is an open access article under the CC-BY-SA license
https://doi.org/10.31764/ijeca.v1i3.2126

\section{A. INTRODUCTION}

Indonesia has a philosophy that became the basis for involving Indonesia with all its aspects is called Pancasila. This also explains that the value of Indonesian society is unity. The fourth paragraph in the opening of Indonesia's basic rules which was passed in 1945 (1945 Constitution) also illustrates the value of peace and social justice. The essence of this concept is to create integration and social harmony in Indonesia. However, there are several conflicts that threaten integration and reflect disharmony in community conflicts.

Problems of disintegration and social disharmony usually occur with the existence of individualism in human life. We all of course still remember how the Jakarta election process a few years ago. Religious sentiment is so thick that it causes horizontal friction which is allegedly the cause of the division of society into groups of "tadpoles" and "shucks". We can watch the debates between the two groups is not unlike making the distance between the two parties are 
more strained. In fact, there is no doubt it is still felt to this day. Hatred, enmity and even persecution that led to iron bars like death that picked up, did not know the place, age, and gender. Even strangely, this kind of moral decline was more dominant outside the Jakarta Province, namely West Java with the Sundanese identity.

From here at least we can see that Sundanese society seems to have forgotten - not even an exaggeration to say lose the character attached to him, which is true with these characters all forms of hatred, hostility and persecution can be avoided. So that character education is considered very important to be better understood even to be implemented in everyday life. On the other hand, now Indonesia has entered the Industrial Era 4.0 and towards the Industrial Era 5.0 where character education is important to be discussed (Sulhan, 2018).

Education is a social institution that functions to provide certain values in the maturity of society towards a new social system that is following the direction of changing times. Therefore education and culture are two things that can not be separated (Tabroni, 2007).

Especially in West Java with Sundanese culture, culture-based character education is considered important to be explored. Then what is the most important aspect of Sundanese culture as the identity of the people of West Java? The author will try to answer that question even though I am aware that this small paper does not represent the problems that have been mentioned. But at least the authors try hard to discourse.

\section{B. METHODS}

This research was conducted using descriptive qualitative research methods. The research data is taken from the author's observations that are felt and experienced in everyday life. Researchers also collected several theories from experts relevant to the topics discussed to support the results of the study

\section{RESULT AND DISCUSSION}

\section{Character Education}

Nowadays the character education discourse has entered a new phase in the world treasury of education. Various countries in the world have focused on preparing a quality generation with this character education capital. Not only for the sake of individuals citizens but to citizens as a whole. Character education can be interpreted as the deliberate us of all dimensions of school life to foster optimal character development (the deliberate effort of all dimensions of social life to help form character optimally) (Dalmeri, 2014).

The character comes from the character of the French word, and the Latin character, which means "sign, distinctive quality" from Greek is "charassein" which is defined as "giving meaning or carving" (Sulasmono et al., 2017). In terminology, the character is an inner disposition who is capable of responding to situations in a morally good way (Lickona, 1991). In other literature, it is said that character education is a deliberate effort to help someone so that he can understand, pay attention, and carry out core ethical values. And more broadly he mentions character education is a deliberate (conscious) effort to realize virtue, that is a good quality of humanity objectively, not only good for individuals but also good for society as a whole (Lickona, 2004). Thomas Lickona said that character has three parts that can not be separated from each other, namely moral knowledge, moral feeling, and moral action (Zuchdi, 2010). So the good character that is a series of activities from the 
knowledge of the good intentions of the best then cause the eventually implemented by doing good.

Darmiyati Zuchdi stated that character education is comprehensive, related to all related and integrated aspects. Character education that relies on just one strategy is not sufficient to make students moral. Thus, it is necessary to use some of the approaches proposed by Kirschenbaum called the comprehensive approach. The term "comprehensive approach" in character education includes the following aspects: content, methods, processes, subjects, and evaluation (Zuchdi, 2010). Specifically mentioned that the content or character education materials can be categorized into three moral values: moral to God, others, and the environment (Nurul, 2010).

Matthew Davidson, Thomas Lickona, and Vladimir Khmelkov claim that there is a role for characters in all achievements in school, both curricular or non-curricular activities (Davidson et al., 2007). The study was conducted in 24 good schools in the US. The findings indicate that the character is composed of two major parts, namely the character of the performance and moral character. The character of work involves all the values that enable people to actualize their potential in the classroom or workplace. Then study conducted by Jacques S. Benninga, Marvin W . Berkowitz, Phyllis Kuehn, and Karen Smith of the relationship between character education and school performance in several elementary schools in California concluded that the schools that teach p Education characters seriously tend to have higher academic achievement (Benninga et al., 2003).

\section{Culture-Based Character Education}

The culture of a nation is an identity that must be studied in its entirety and dynamically. Because of that, it is necessary to maintain intelligence in interpreting a cultural impact. Culture has the meaning of innovation and change, and culture is the source of change itself (Sulhan, 2018). Culture-based character education is education that teaches to be always close to the concrete situation at hand (Istiawati, 2016). Culture-based character education defines culture as something that must be learned and transformed into the next generation.

The functional relationship between education and culture contains meaning, among others; the first is reflective, which is a picture of the culture that is taking place at the moment, and the second is progressive, that is education moves to reform, bringing culture towards the advancement of civilization progress. Both of these are the meanings of character education, which is where the educational process is an individual effort as well as innovative and dynamic efforts in the context of facing the changing times for the better (Sulhan, 2018). So it can be said that character education is the end of the education process.

Culture-based character education takes the same theory as character education itself, which is moving from knowing to doing or acting (Lickona, 1991). William Kilpatrick mentioned that one of the causes of the inability of a person to behave well even though he already knew the good (moral knowing) was because he was not trained to do good (moral doing). Referring to these thoughts, the success of character education is very dependent on the presence or absence of knowing, loving, and doing or acting in the organization of character education (Priyatna, 2017).

Moral knowing as the first aspect has six elements, namely moral awareness, knowledge of moral values, determination of perspective, moral logic, the courage to take an attitude (decision making), and self-knowledge. These six elements are the components that must be taught to fill their cognitive domains (Priyatna, 2017). 
Moral loving or moral feeling is strengthening the emotional aspects of students to become human characters. This reinforcement is related to the forms of attitude that must be felt by students, namely awareness of identity, self-confidence, sensitivity to the suffering of others (empathy), love of truth (loving the good), self-control, and humility. After these two aspects are realized, then moral acting as an outcome will easily appear in a person. There is another opinion that asserts that character is a character that is directly driven from the brain, so the three stages need to be presented through logical, rational and democratic ways. So that the behavior that appears is really a character, not a mask (Priyatna, 2017).

Paulo Freire states that by facing concrete problems and situations, students will be increasingly challenged to respond critically. This is consistent with the opinion of Suwito (2008) who suggests that the pillars of local wisdom education, including: (1) educated humans are built based on the recognition of human existence since in the womb; (2) education must be based on truth and virtue, far from wrong ways of thinking and careless actions; (3) education must develop moral, spiritual (affective domain) aspects and not just cognitive and psychomotor domains; and (4) The need for culture, education and tourism is developed in synergy with character education. In short, local knowledge is the formation of noble character capital. A noble character is a national character who always acts with awareness, primordialism, and self-control (Sulasmono et al., 2017).

It is hoped that character-based character education in addition to advancing the treasures of Indonesian culture can also enhance the dignity of the Indonesian nation on the world stage. Culture as a local idea that is followed by the community has a big contribution in shaping character education. Cultural values of local wisdom in the community are very closely related to the character that will be formed. Unwittingly the cultural value of life in society and can be used as the content of character education. Although the values of local wisdom cultural traditions are different but have similarities when traditional values are synchronized with psychological or sociocultural processes.

Character configurations in the context of the totality of the social-cultural processes can be grouped into spiritual processing (spiritual and emotional quotient); if thought (intellectual quotient); sports and kinesthetic (physical and kinesthetic quotient); and if the taste and intention (affective and creativity quotient). The relationship with local wisdom as the basis of character, taste, and intention has a very large contribution. With this local cultural wisdom will be more meaningful in planting one's character (Mustadi, 2010). Sundanese culture in particular, which predominantly lives and continues to grow in West Java, has a very rich and diverse source of values, so the inculcation of Sundanese culturebased characters needs to be implemented immediately.

\section{Sundanese Culture Wisdom}

Cultural wisdom is defined as the idea of life. Such thinking is based on clear thinking, pure thought, and contains positive things. Cultural wisdom can be translated as the work of the mind, deep feelings, and character (Sulasmono et al., 2017). Cultural wisdom is closely related to ethnic terms. Ethnic groups are people who are bound by the awareness and identity of "cultural unity", and the language element is their trademark (Nuraeni \& Alfan, 2012).

So Sundanese cultural wisdom can be defined as a social and cultural condition which contains cultural treasures that value and are adaptive to the natural surroundings, and are arranged steadily in the customs and traditions of a society. Although often considered 
obsolete, the values they teach and the practices they practice are still the best way to preserve the environment in post-modern times (Indrawardana, 2013). Sundanese society is not a group of people that connects individuals and individuals to the community, but is a unity that is closely attached by the norms of life because of history, tradition or religion. As the smallest unit, the family has a role as a glue for one another to be drawn to a wider area, namely village to village.

One philosophy of Sundanese society is cooperation. Between one family and another, an unwritten agreement must help one another. Motto such as sapapait, samamanis, is a series of lives that feel each other fellow citizens or families. Therefore, Sundanese society is not made up of alliances of individuals, but is a unity of form one for all and all for one (Endraswara, 2005).

In the Sundanese cultural treasures, there is also what is known as the way of life. Zainal Abidin quoted by Tabroni divides the Sundanese view of life into five parts. First, humans as individuals. Second, humans and society. Third, humans with nature. Fourth, humans with God. Fifth, humans in pursuit of physical progress and inner satisfaction (Tabroni, 2007). Whereas in the oral tradition, some characteristics that are considered good by the Sundanese are classified in four broad categories, namely reason, mind, spirit, and behavior (Tabroni, 2007).

In the category of reason, what is considered good is smart, clever, intelligent, clever, wise, wide-ranging experience and upholds the truth. In the category of benevolence, which is considered to be good, that is honest, pure, has an attitude, piety, is not timid, siger tengah (moderate), bageur (good), wise, populist, has a sense of shame, obedient to parents, has selfesteem, loyal trustworthy and others.

In the category of spirit, which is considered good from Sundanese culture, namely idealism, patience, trust in destiny, steadfast, have enthusiasm for learning, willing to endeavor, be diligent, better to die than live humiliated, brave, noble, resilient, resilient to temptation, and devoted in prayer. In the category of behavior, what is considered good is simple, mature, calculating, helpful, polite, alert, conscientious, self-aware, friendly, not cunning, keeping promises, saving, not saying much, and having skills.

While Sundanese cultural wisdom which is considered important is also reflected in the language which is often referred to as babasan or paribasa. Babasan and paribasa are traditional expressions or Sundanese idioms. The contents of babasan and paribasa are local Sundanese values and wisdom in general. In the babasan and paribasa a lot of local wisdom contained therein. Local wisdom is the character or philosophy of the Sundanese people in general. These values and local wisdom must be maintained and used as the philosophy of Sundanese life, as a form of values contained in babasan and paribasa.

Babasan and paribasa have rules that are fixed or often called the language of pakeman, so that babasan and paribasa cannot be changed or changed. This is based on that babasan and paribasa have fixed rules that are intended to keep the values of babasan and paribasa maintained (Masduki, 2015). Such as guidance for harmonious life (ka cai jadi saleuwi ka darat jadi salogak, sareundeuk saigel sabobot sapihanean), prioritizing togetherness (sapapait samamanis), having a fair consideration (landung kandungan laer aisan), having a far-sighted future so that they are ready to face trials (dipayung samemeh hujan), must adjust to the new environment (pindah cai pindah tampian), help each other in doing something (paheuyeukpaheuyeuk leungeun), must not despair (genteng-genteng ulah poho), self-knowledge (ngukur 
ka kujur nimbang ka awak), and so on (Tabroni, 2007). Masduki is more comfortable to call this traditional expression by the name of folklore (Masduki, 2015).

Besides Sundanese people also have a pro-social behavior contained in the terms silih asah, silih asih, silih asuh, this is part of the teachings of Sundanese cultural wisdom that has a strong correlation with Islamic teachings. We can see the word of God that teaches about the importance of advising one another among human beings on the path of piety and truth:

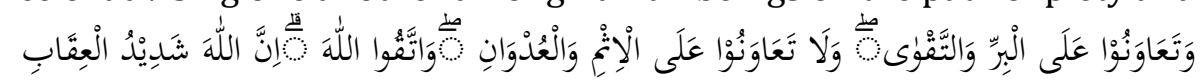

"And help in helping virtue and piety, and do not help in doing sin and enmity. Fear God, truly, Allah is very severe in torment." (Surat al-Maidah: 02)

Pro-social behavior, silih asah, silih asuh, silih asih if taken to interpret the theory of Benjamin S. Bloom in his book Taxonomy of Education of Objectives, Cognitive Domain can be equated with cognitive, affective, and psychomotor domains. Because of the sharpening of the orientation of its value to the improvement of the quality of thinking, hone the ability to sharpen the mind with the forging of knowledge and experience. The meaning of compassion, the orientation of its value to the meaning of behavior or attitudes of individuals who have compassion, grace, sympathy for the life around them or have a high social sense. While the meaning of penance, the value orientation is compassion in real action, one's pragmatic attitude, self-existence, applying one's potential in society. To the older must be more respectful, to each other must take care of each other, the younger must be able to protect and set a good example (Masduki, 2015).

In a nutshell, view of life, oral traditions, babasan or paribasa, and pro-social behavior are dimensions that elevate the values of Sundanese cultural characters to the grassroots. These dimensions can be classified into 2 (two), namely prosperity/welfare and peace/kindness and this feels in harmony with the mandate of Hasanah (Hasanah et al., 2016). For more details, we can consider the following picture:

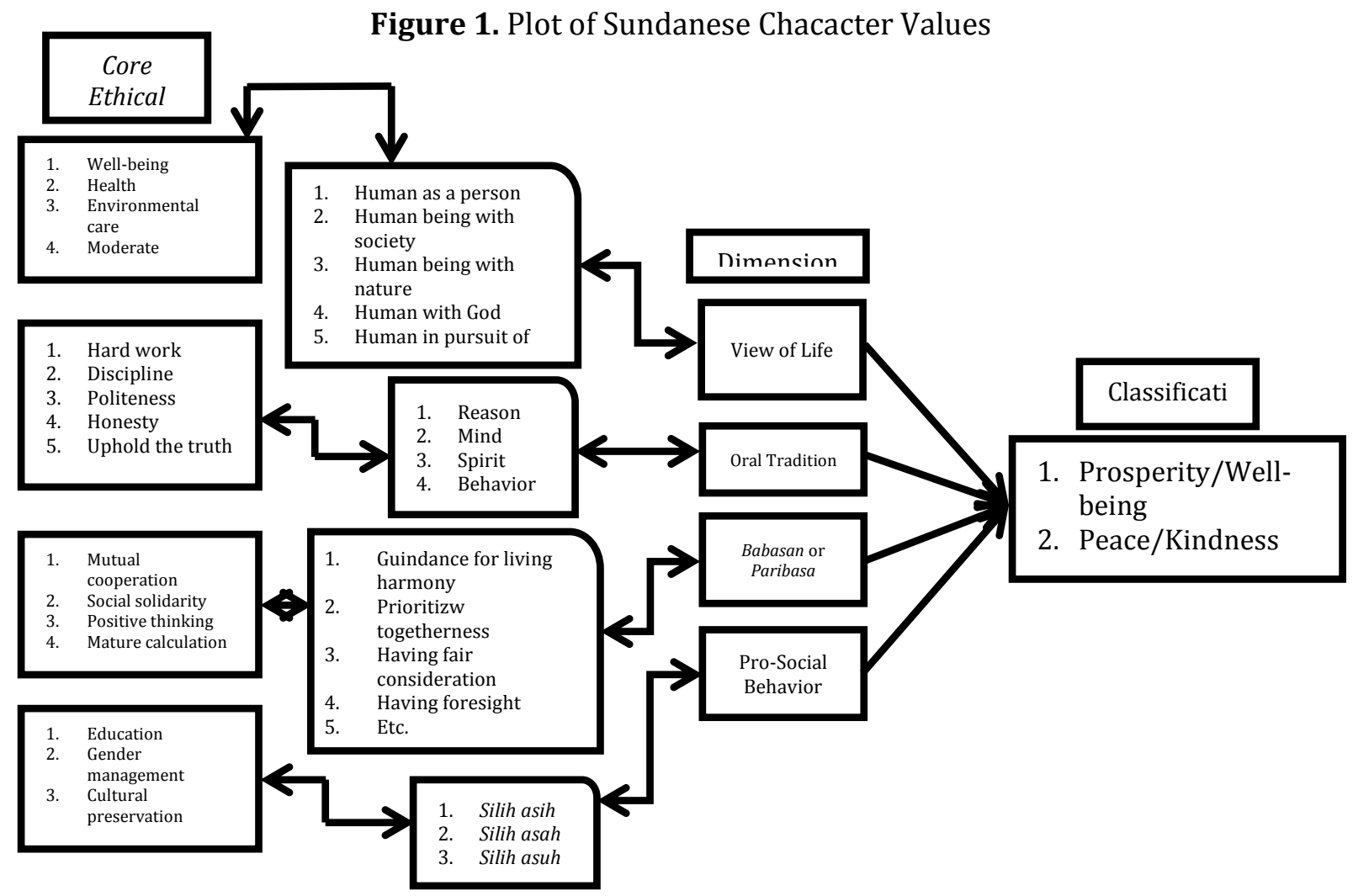


The values of Sundanese cultural wisdom can be found in various media, such as inscriptions, chronicles, historical texts, literary works, folklore, rhymes, sisindiran, the sayings and daily life of the Sundanese people (Hasanah et al., 2016).

In closing, the values of Sundanese character noted earlier is a value that is very relevant to the essential Qur'an. Based on the cultural wisdom inherent in the Sundanese people, it should be able to create a climate that brings the community to Islamic values. Thus, we will go to the society that Islam aspires for, namely a society where every aspect of life breathes religious values.

\section{CONCLUSION AND SUGGESTIONS}

Sundanese culture-based character education needs to be continuously implemented and developed in the world of education in West Java. So hopefully the community can become an identity that always holds the wisdom of a good Sundanese culture. Some ethical values of Sundanese culture can be classified into 2 (two), namely prosperity/well-being and peace/kindness which are all reflected in the dimensions of outlook on life, oral traditions, language, and pro-social behavior.

Then the role of educational institutions needs to be improved in implementing Sundanese culture-based character education. more research is needed on the role of education in this matter.

\section{ACKNOWLEDGEMENT}

The authors thank the International Journal of Education and Curriculum Application for providing the opportunity to publish this article. The author also thanks Prof. Aan Hasanah, M.Ed. who has provided guidance and input in improving this text.

\section{REFERENCES}

Benninga, J. S., Berkowitz, M. W., Kuehn, P., \& Smith, K. (2003). The Relationship of Character Education Implementation and Academic Achievement in Elementary Schools. Journal of Research in Character Education, 1(1), 19-32.

Dalmeri. (2014). Pendidikan untuk Pengembangan Karakter (Telaah terhadap Gagasan Thomas Lickona dalam Educating for Character). Al-Ulum IAIN Sultan Amai Gorontalo, 14(1), 269-288.

Davidson, M., Lickona, T., \& Khmelkov, V. (2007). Smart and Good Schools. Education Week. http://www.edweek.org/ew/articles/2007

Endraswara, S. (2005). Budaya Jawa, Mutiara Adiluhung Orang Jawa. Gelombang Pasang.

Hasanah, A., Gustini, N., \& Rohaniawati, D. (2016). Nilai-nilai Karakter Sunda (Internalisasi Nilai-Nilai Karakter Sunda di Sekolah). Deepublish.

Indrawardana, I. (2013). Kearifan Lokal Adat Masyarakat Sunda dalam Hubungan dengan Lingkungan Alam. Komunitas: International Journal of Indonesian Society and Culture, 4(1), 1-8. https://doi.org/10.15294/komunitas.v4i1.2390

Istiawati, N. F. (2016). Pendidikan Karakter Berbasis Nilai-Nilai Kearifan Lokal Adat Ammatoa dalam Menumbuhkan Karakter Konservasi. CENDEKIA: Journal of Education and Teaching, 10(1), 1-18. https://doi.org/10.30957/cendekia.v10i1.78

Lickona, T. (1991). Educating for Character: How Our School Can Teach Respect and Responsibility. Bamtam Books.

Lickona, T. (2004). Character Matters: How to Help Our Children Develop Good Judgment, Integrity, and Other Essential Virtues. Simon \& Schuster. 


\section{2 | IJECA (International Journal of Education and Curriculum Application)}

Vol. 1, No. 2, December 2018, pp. 15-22

Masduki, A. (2015). Kearifan Lokal Orang Sunda dalam Ungkapan Tradisional di Kampung Kuta Kabupaten Ciamis. Patanjala: Jurnal Penelitian Sejarah dan Budaya, 7(2), 295-310. https://doi.org/10.30959/patanjala.v7i2.102

Mustadi, A. (2010). Pendidikan Karakter Berwawasan Sosiokultural (Sociocultural based Character Education) di Sekolah Dasar, Daerah Istimewa Yogyakarta (DIY). http://staff.uny.ac.id/sites/default/files/penelitia n n/dr-ali-mustadi-mpd/7-artikelpendidikankarakter-berwawasan-sosio-kultural-terbitmajalah-dinamika-pendidikan-2011_2.pdf.

Nuraeni, H. G., \& Alfan, M. (2012). Studi Budaya di Indonesia (Cetakan I). CV Pustaka Setia.

Nurul, Z. (2010). Pendidikan Moral dan Budi Pekerti. Bumi Aksara.

Priyatna, M. (2017). Pendidikan Karakter Berbasis Kearifan Lokal. Edukasi Islami : Jurnal Pendidikan Islam, 5(10), 1311-1336. https://doi.org/10.30868/ei.v5i10.6

Sulasmono, P., Ekosiswoyo, R., \& Widodo, J. (2017). The Integration of Local Cultural Wisdom Values in Building The Character Education of Students. International Journal of Education and Research, 5(6), 151-162.

Sulhan, M. (2018). Pendidikan Karakter Berbasis Budaya dalam Menghadapi Tantangan Globalisasi. Jurnal Visipena, 9(1), 159-172.

Tabroni, R. (2007). Transformasi Sosial Berbasis Kearifan Lokal dalam Konteks Masyarakat Jawa Barat yang Multikultural (Cetakan Pertama). Sekretariat Daerah Provinsi Jawa Barat.

Zuchdi, D. (2010). Humanisasi Pendidikan-Menemukan Kembali Pendidikan yang Manusiawi. Bumi Aksara. 